\title{
Future Scenarios of Impacts to Ecosystem Services on California Rangelands
}

\begin{abstract}
$7 \Gamma$ he 18 million acres of rangelands in the Central Valley of California provide multiple benefits or "ecosystem services" to people -including wildlife habitat, water supply, open space, recreation, and cultural resources. Most of this land is privately owned and managed for livestock production. These rangelands are vulnerable to land-use conversion and climate change. To help resource managers assess the impacts of land-use change and climate change, U.S. Geological Survey scientists and their cooperators developed scenarios to quantify and map changes to three main rangeland ecosystem serviceswildlife habitat, water supply, and carbon sequestration. Project results will help prioritize strategies to conserve these rangelands and the ecosystem services that they provide.
\end{abstract}

The Central Valley of California, the surrounding foothills, and the inner Coast Ranges include more than 18 million acres of rangelands. Much of the Central Valley grasslands and foothills are privately owned and managed as rangelands for livestock production. Many sites on these rangelands provide crucial habitat for what were previously wider-ranging species, such as Swainson's hawk (Buteo swainsoni), California tiger salamander (Ambystoma californiense), and San Joaquin kit fox (Vulpes macrotis mutica). Ranching is a vital part of the State's economy, providing jobs and important food supplies. In addition, ranches generate other "ecosystem services," defined as human benefits provided by natural ecosystems, which carry considerable economic value. Most of the water consumed by Californians flows over rangeland, and associated grasslands and oak woodlands are important for "carbon sequestration." Carbon sequestration is the capture and long-term storage of carbon dioxide $\left(\mathrm{CO}_{2}\right)$, a greenhouse gas associated with climate change. Some ranches in California have been in existence for more than 100 years and are an important part of the State's historical heritage.

Much of California's rangeland is being rapidly converted to urban

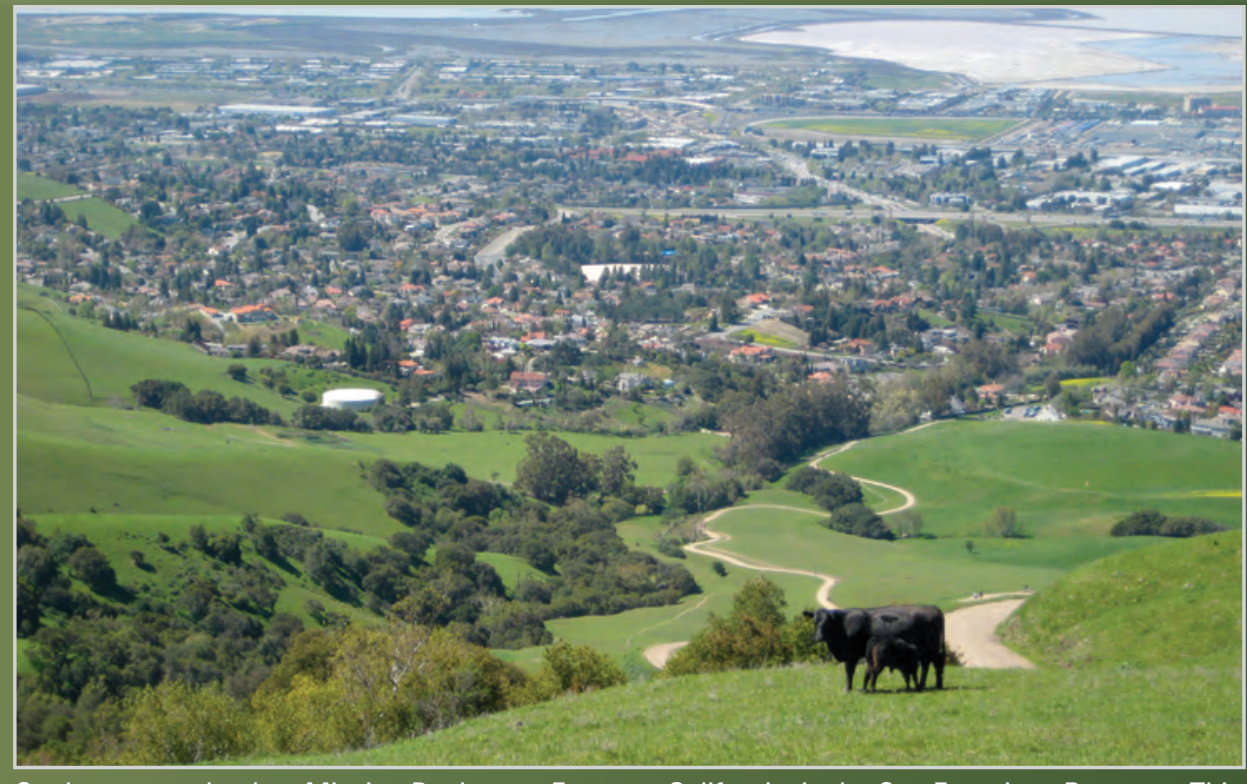

Cattle on rangeland on Mission Peak, near Fremont, California, in the San Francisco Bay area. This image is an example of the expansion of urban areas into former rangeland. (Photograph courtesy of David Amme, California Native Grasslands Association.)

development and intensive agriculture. In addition, climate change stresses rangelands by potentially changing water availability and species distributions. The interaction between climate change and land-use change can severely affect rangeland ecosystem services. Wildlife habitat may become fragmented, and rangelands may lose the capacity to capture, filter, and release water slowly, which could affect watershed health.

It is not known exactly where and how much change will occur to California rangelands in the future. Given this uncertainty, planners use scenarios to consider a variety of possible futures to prepare for the potential impacts of future climate and land-use change. A scenario is a plausible yet simplified description of how the future may develop based on a set of assumptions about the main causes of change. Scenarios are not predictions but are based on a narrative storyline about the future.

\section{Scenarios for California Rangelands}

The U.S. Geological Survey (USGS) Western Geographic Science Center (WGSC), USGS California Water Science Center (CAWSC), and Defenders of Wildlife have been working with ranchers and several organizations within the California Rangeland Conservation Coalition (http://www.carangeland.org/) to develop six scenarios organized around the management question "How can we maintain viable ranchland and their ecosystem services in light of future integrated impacts?” The scenarios represent alternative futures of climate, land-use, and hydrological change for the California Rangeland Conservation Coalition focus area, which includes the State's Central Valley, the surrounding foothills of the Sierra Nevada to the east, and most of the southern inner Coast Ranges to the west. These scenarios were used to quantify and map three main rangeland ecosystem services-wildlife habitat, water supply, and carbon sequestration. These results were used to conduct an economic analysis associated with changes in these services.

The scenarios are based on the storylines of the Intergovernmental Panel on Climate Change (IPCC) Special Report on Emission Scenarios (SRES) A2, A1B, and B1 (http://www.ipcc.ch/pdf/ special-reports/spm/sres-en.pdf). Three downscaled land-use/land-cover (LULC) change scenarios were each paired with two downscaled global climate models (a warm 
wet future and an even warmer dry future). Scenarios vary by extent and distribution of development, irrigated agriculture, and future conservation lands and changes in climate and hydrology. A growth model, FORE-SCE (FOREcasting SCEnarios of future land cover), was used to produce maps of LULC change yearly from 2006 to 2100 at a spatial resolution of 250 meters (1 meter $=3.28 \mathrm{feet}$ ).

The USGS Basin Characterization Model was used to model change in runoff, groundwater recharge, and climatic water deficit (a landscape stress indicator) based on climate change. For six case-study watersheds, it was also used to model change in stream discharge based on future development and climate change. Land-use change was quantified in priority conservation areas mapped by The Nature Conservancy in 2007. Change in rangeland soil carbon stocks was tracked using USGS General Ensemble Biogeochemical Modeling System output.

\section{Results}

A Web site, http://climate.calcommons. org/aux/rangeland/index.html, provides a visualization tool to view changes in ecosystem services across scenarios and years. Here results are presented for the California Rangeland Conservation Coalition's focus area at the scale of 8-digit hydrologic unit watershed boundaries. The Web site also provides access to download underlying raster datasets at 250- to 270-meter resolution. The visualization tool includes maps of (1) change in the percentage of watershed area with critical habitat relative to 2010; (2) percent change in grassland-soil carbon-sequestration potential; (3) percent change in climatic water deficit relative to the 1981-2010 climate period; (4) ratio of recharge to runoff for three 30-year climate periods; (5) water-wildlife hotspots-areas where

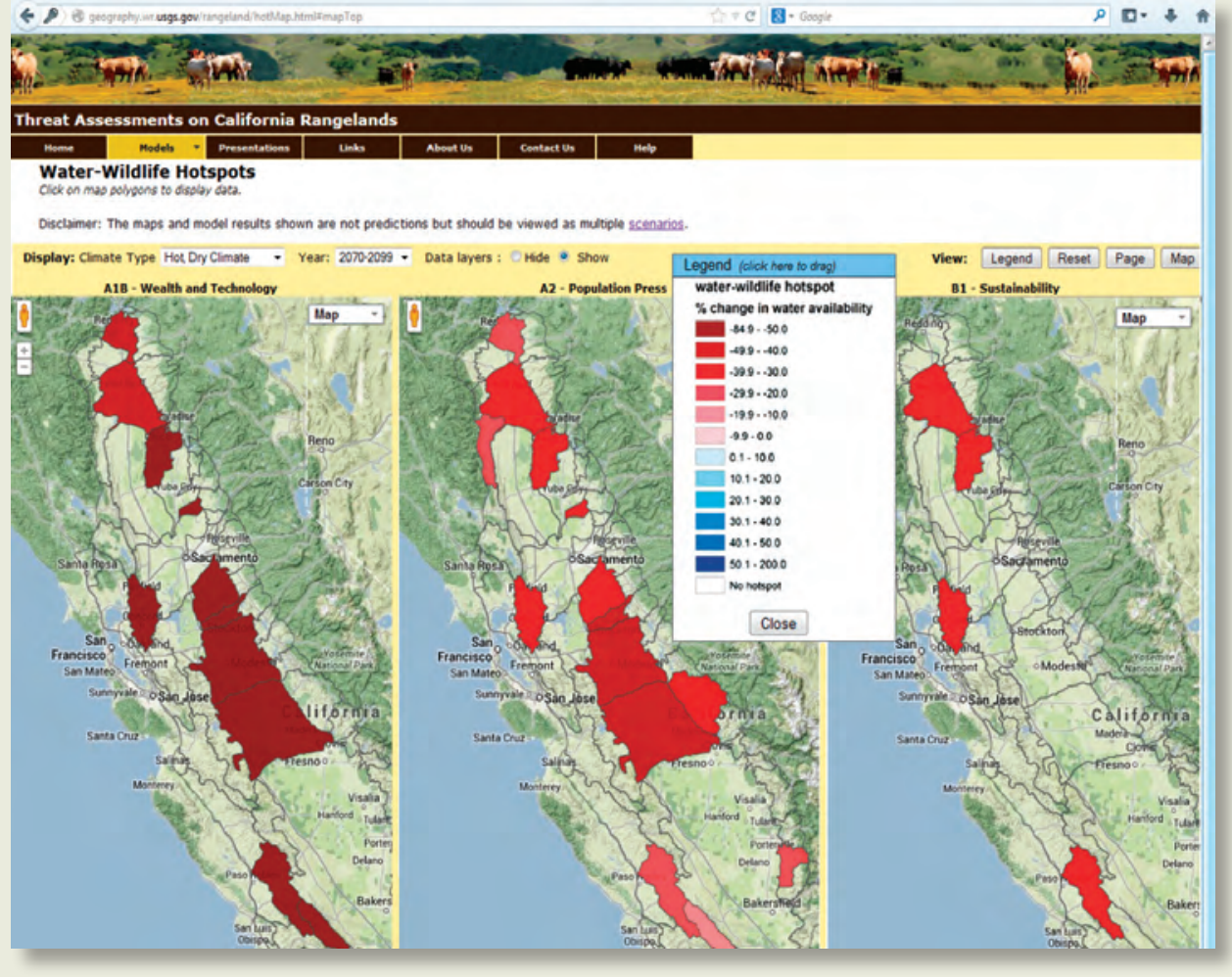

Screenshot of a Web-based visualization tool, developed by U.S. Geological Survey scientists, used to view possible future changes in rangeland ecosystem services for the California Rangeland Conservation Coalition focus area. Results can be compared across three scenarios simultaneously. The tool is available at http://climate.calcommons.org/aux/rangeland/index.html. changes in water availability (recharge plus runoff) and loss of critical habitat coincide; and (6) average percent change in multiple ecosystem services from 2010 to 2040.

Raster data available for download includes (1) baseline soil organic carbon; (2) soil depth; (3) LULC change; (4) conversion of critical habitat; (5) climatic water deficit; (6) recharge, runoff, and recharge-to-runoff ratio; and (7) water availability.

The future scenarios developed by WGSC and CAWSC scientists will assist ranchers, watershed groups, planners, and land managers in ensuring the continuation of ecosystem services provided by California rangelands. The scenarios will also assist government agencies with the design of

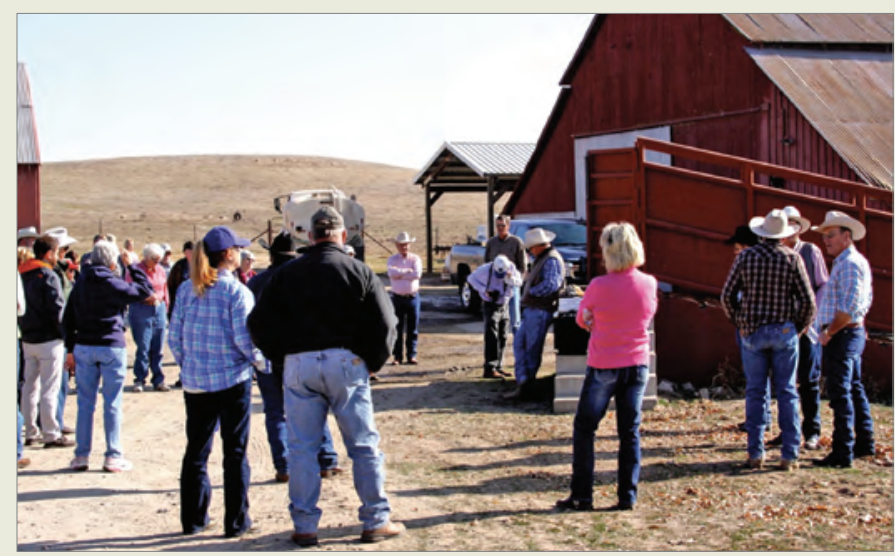

Ranchers, scientists, and other participants of the 9th Annual California Rangeland Conservation Coalition Summit attend a field trip to Ichord Ranch in Stanislaus County, California. (Copyrighted photograph courtesy of DontFenceMelnPhotos. com.) effective conservation plans that consider both climate change and land-use change, inform water agencies about potential changes to water supply, and help conservation organizations prioritize their actions. The development of the scenarios is only part of USGS efforts to better understand the causes and consequences of land-use change and climate change.

Kristin Byrd, Pelayo Alvarez, Lorraine Flint, and Alan Flint

Edited by James W. Hendley II Design by Jeanne S. DiLeo

COOPERATING ORGANIZATIONS Defenders of Wildlife

For more information contact: Kristin Byrd

U.S. Geological Survey

345 Middlefield Road, MS 531

Menlo Park, CA 94025

Tel. (650) 329-4279

kbyrd@usgs.gov

http://geography.wr.usgs.gov/

http://climate.calcommons.org/content/integrating-

http://climate.calcommons.org/aux/rangeland/index.html

This Fact Sheet and any updates to it are available online at http://pubs.usgs.gov/fs/2014/3019/
California Rangeland Conservation Coalition science-decisions/ 